\title{
Chemical and Functional Characterization of Sarcoplasmic Proteins from Giant Squid (Dosidicus gigas) Mantle
}

\author{
Rosa Linda Lopez-Enriquez, ${ }^{1}$ Victor Manuel Ocano-Higuera, ${ }^{2}$ Wilfrido Torres-Arreola, ${ }^{1}$ \\ Josafat Marina Ezquerra-Brauer, ${ }^{1}$ and Enrique Marquez-Rios ${ }^{1}$ \\ ${ }^{1}$ Departamento de Investigación y Posgrado en Alimentos, Universidad de Sonora, Rosales y Niños Héroes, S/N, P.O. Box 1658, \\ 83000 Hermosillo, SON, Mexico \\ ${ }^{2}$ Departamento de Ciencias Químico Biológicas, Universidad de Sonora, Rosales y Niños Héroes, S/N, P.O. Box 1658, \\ 83000 Hermosillo, SON, Mexico
}

Correspondence should be addressed to Enrique Marquez-Rios; emarquez@guayacan.uson.mx

Received 14 May 2015; Accepted 5 July 2015

Academic Editor: Ioannis G. Roussis

Copyright (C) 2015 Rosa Linda Lopez-Enriquez et al. This is an open access article distributed under the Creative Commons Attribution License, which permits unrestricted use, distribution, and reproduction in any medium, provided the original work is properly cited.

\begin{abstract}
Modification of $\mathrm{pH}$ and $\mathrm{NaCl}$ concentration changed the physicochemical properties of sarcoplasmic proteins (SP) from jumbo squid mantle and consequently their functional properties. Better results of emulsifying activity index (EAI) and foam capacity (FC) were exhibited at $\mathrm{pH} 11$ in $\mathrm{NaCl}$ absence due to higher solubility. But better emulsifying stability index (ESI) was obtained at $\mathrm{pH} 11$ in $0.5 \mathrm{M} \mathrm{NaCl}$, while, foaming stability (FS) was better at $\mathrm{pH}$ near to isoelectric point (pI). These results suggest that SP from jumbo squid may be a promising ingredient, whose functional properties can be manipulated by changing $\mathrm{pH}$ and $\mathrm{NaCl}$ concentration.
\end{abstract}

\section{Introduction}

The giant squid (Dosidicus gigas) represents one of the most important fisheries in Mexico in terms of catch volumes. However, it is an underutilized and undervalued resource despite its abundance and its nutritional value [1]. In order to increase its value and promote its consumption, several researches have been carried out focused on obtaining protein concentrates from its mantle. Nonetheless, the conventional process for production thereof generates high volumes of effluent with high content of soluble protein called sarcoplasmic proteins, which can cause contamination problems if they are not treated before disposal [2].

Sarcoplasmic proteins represent 20 to $40 \%$ of the total muscle proteins. These proteins are globular and exhibit solubility in water and diluted salt solutions and are constituted mainly by enzymes involved in cellular metabolism [3]. There are few studies about the protein composition, structure, and functionality of the sarcoplasmic proteins, in comparison to myofibrillar proteins. Therefore, their study could provide information for use as food ingredients. The above would not only reduce pollution problems, it could also make the use of marine resources more efficient, which is the current trend, not only in fisheries but throughout the food industry.

The effect of the sarcoplasmic proteins has been studied on the textural quality of gels made from myofibrillar proteins of various species of fish, obtaining favorable results $[4,5]$. Additionally, other functional properties have been explored, such as emulsifying and foaming property $[6,7]$, demonstrating that sarcoplasmic proteins have potential to be used as ingredients in the food industry.

In recent years, various methods have been studied to induce improvement of functional properties of proteins, due to the fact that alternative processes based on extrinsic factors such as $\mathrm{pH}$ shift, ionic strength, and temperature may induce conformational changes in proteins, which in turn can improve their functional properties [6]. In this sense, Hemung et al. [8] demonstrated that the sarcoplasmic proteins of sea bream (Nemipterus hexodon), treated in acid and alkaline conditions, followed by neutralization, exhibited 
conformational changes which improved the emulsifying activity. In another study, Hemung et al. [8] studied the effect of $\mathrm{pH}$, without subsequent neutralization of the sarcoplasmic proteins from the same species, and found that, in acidic conditions, proteins exhibited conformational changes which in turn induced the increased emulsifying activity.

Nowadays there are no researches focused on the study of sarcoplasmic proteins from giant squid mantle. Consequently, due to the importance of generating new knowledge about these proteins, which would allow their use as a food ingredient, the objective of this research is to recover sarcoplasmic proteins from giant squid mantle and evaluate the $\mathrm{pH}$ and ionic strength effects on the physicochemical and functional properties.

\section{Materials and Methods}

2.1. Raw Material. Jumbo squid (D. gigas) was harvested off the coast of Kino Bay, Sonora, Mexico, in June, 2014. Ten specimens were decapitated and gutted on site and were then washed with freshwater at room temperature $\left(25^{\circ} \mathrm{C}\right)$. The mantles (experimental samples) were bagged and placed in alternating layers of ice-squid-ice in a portable cooler and transported to the laboratory. Squid mantles exhibited a length of $37.85 \pm 4.1 \mathrm{~cm}$ and a total weight of $827.5 \pm$ $82.75 \mathrm{~g}$. The elapsed time between capture and reaching the laboratory did not exceed $12 \mathrm{~h}$.

2.2. Sarcoplasmic Proteins Preparation. Frozen squid mantle was thawed at $4-5^{\circ} \mathrm{C}$ for $12 \mathrm{~h}$, minced, and mixed with cold distilled water $\left(\leq 4^{\circ} \mathrm{C}\right)$ at a ratio of $1: 3$ (mince: water). Mixture was then homogenized at $1000 \mathrm{rpm}$ for $1 \mathrm{~min}$ using a tissue homogenizer (Wisd; WiseTis HG-15D; Witeg, Germany). The homogenate was centrifuged in a refrigerated centrifuge at $12000 \times \mathrm{g}$ for $20 \mathrm{~min}$ at $4^{\circ} \mathrm{C}$ (Thermo Scientific; Sorvall Biofuge Stratos; MA, USA). The supernatant obtained was considered as the sarcoplasmic proteins (SP) fraction and was analyzed for protein concentration according to the Lowry method [9], using bovine serum albumin as standard.

2.3. Modification of $\mathrm{pH}$ and $\mathrm{NaCl}$ Concentration. Twenty $\mathrm{mL}$ aliquots of $\mathrm{SP}$ were added to $\mathrm{NaCl}(0,0.2$, and $0.5 \mathrm{M})$ and the $\mathrm{pH}$ was adjusted to $3.0,5.0,7.0,9.0$, or 11.0. Then, the final volume of the homogenates was brought to $25 \mathrm{~mL}$ (using cold distilled water) and stirred for $30 \mathrm{~min}$ at $4^{\circ} \mathrm{C}$. The adjusted solutions were used to determine protein solubility, emulsifying, and foam properties.

2.4. Protein Solubility. In order to determine the effect of different $\mathrm{pH}$ levels and $\mathrm{NaCl}$ concentrations on the solubility of SP, all solutions previously prepared were centrifuged at $12000 \times \mathrm{g}$ for $20 \mathrm{~min}$ at $4^{\circ} \mathrm{C}$ (Thermo Scientific; Sorvall Biofuge Stratos; MA, USA). Protein concentration of the supernatants was analyzed by Lowry method [9]. Protein solubility was expressed as the percentage of protein remaining soluble after centrifugation in relation to the total protein present in SP. Supernatants obtained were used for the determination of protein patterns by sodium dodecyl sulfate-polyacrylamide gel electrophoresis (SDS-PAGE), surface hydrophobicity $\left(\mathrm{S}_{0}\right.$-PRODAN and $\mathrm{S}_{0}$-ANS), and total sulfhydryl $(\mathrm{SH})$ content.

2.5. Electrophoretic Profile (SDS-PAGE). The electrophoretic profile of each protein system was analyzed by means of polyacrylamide gel electrophoresis (PAGE) using a dissociating sodium dodecyl sulfate (SDS) buffer system in a discontinuous gel (4\% stacking gel and $10 \%$ separating gel) according to the method of Laemmli [10]. A Mini-PROTEAN 3 Cell MultiCasting Chamber (Bio-Rad Laboratories, Hercules, CA) was used. Electrophoretic runs were performed at room temperature $\left(25^{\circ} \mathrm{C}\right)$ at $80 \mathrm{~V}$. Thirty $\mu \mathrm{g}$ of protein was loaded into each lane of the gels, and a broad range of molecular weight protein standard solutions (Bio-Rad Laboratories, Richmond, CA) containing myosin $(200 \mathrm{kDa})$, beta-galactosidase $(116 \mathrm{kDa})$, phosphorylase $\mathrm{b}(97 \mathrm{kDa})$, bovine serum albumin $(66 \mathrm{kDa})$, ovalbumin $(45 \mathrm{kDa})$, and carbonic anhydrase $(31 \mathrm{kDa})$ were used. After electrophoresis, the gel was stained with $0.125 \%$ (w/v) Coomassie brilliant blue R-250 in 40\% (v/v) methanol and $7 \%(\mathrm{v} / \mathrm{v})$ acetic acid and the gel was destained with $50 \%$ $(\mathrm{v} / \mathrm{v})$ methanol and $10 \%(\mathrm{v} / \mathrm{v})$ acetic acid.

2.6. Surface Hydrophobicity $\left(S_{0}\right)$. Surface hydrophobicity $\left(\mathrm{S}_{0}\right)$ was determined by the method reported by Alizadeh-Pasdar and Li-Chan [11] with slight modifications. Protein solutions were diluted in order to obtain protein concentrations of $0,0.125,0.25,0.5$, and $0.1 \mathrm{mg} \mathrm{mL}^{-1}$. Four $\mathrm{mL}$ aliquot from each diluted solution was mixed with $20 \mu \mathrm{L}$ of ANS solution (10 mM phosphate buffer, $\mathrm{pH} 7$ ) or $10 \mu \mathrm{L}$ of PRODAN solution (1.4 mM in methanol). ANS samples were set for $10 \mathrm{~min}$ and PRODAN samples were set in the dark for $15 \mathrm{~min}$. Subsequently, the fluorescence intensity of the samples was measured using a spectrofluorometer (Agilent Technologies; Cary Eclipse; CA, USA) at excitation/emission wavelength of 390/470 $\mathrm{nm}$ and 365/465 for ANS and PRODAN, respectively. The surface hydrophobicity index $\left(\mathrm{S}_{0}\right)$ was calculated from the regression slope or net relative fluorescence intensity versus protein concentration $(\%, \mathrm{w} / \mathrm{v})$.

2.7. Determination of Total Sulfhydryl (TSH). Total sulfhydryl (TSH) content, at different $\mathrm{pH}$ levels and $\mathrm{NaCl}$ concentrations, was determined by the method reported by Tadpitchayangkoon et al. [12] with slight modifications. Protein content of each protein solution was adjusted to $1 \mathrm{mg} \mathrm{mL}^{-1}$. $0.5 \mathrm{~mL}$ aliquot of each treatment was mixed with $2 \mathrm{~mL}$ of solubilizing buffer $(0.2 \mathrm{M}$ Tris- $\mathrm{HCl}, 8 \mathrm{M}$ urea, $10 \mathrm{mM}$ EDTA, pH 7.0) and $50 \mu \mathrm{L}$ of Ellman's reagent (10 mM 5,5' dinitrobis [2-nitrobenzoic acid], $0.1 \mathrm{M}$ sodium phosphate buffer, $\mathrm{pH} 7.0$ ). All samples were incubated at $40^{\circ} \mathrm{C}$ for $25 \mathrm{~min}$. The absorbance was measured at $412 \mathrm{~nm}$ using a UV-Vis spectrophotometer (Cary 50; Varian; CA, USA), and SH content was calculated using the extinction coefficient of $13,600 \mathrm{M}^{-1} \mathrm{~cm}^{-1}$.

2.8. Emulsifying Properties. The emulsifying activity index (EAI) and emulsifying stability index (ESI), at different $\mathrm{pH}$ levels and $\mathrm{NaCl}$ concentrations, were determined by 
turbidimetric technique of Pearce and Kinsella [13] with some modifications. Each protein solution was adjusted to $0.5 \mathrm{mg} \mathrm{mL}^{-1}$. Protein solutions were mixed with canola oil at a ratio of $1: 1$ and homogenized at $13500 \mathrm{rpm}$ for $1 \mathrm{~min}$ using a tissue homogenizer (Wisd; WiseTis HG-15D; Witeg, Germany). To determine EAI, the emulsions phases were allowed to separate during $1 \mathrm{~min}$ and the lower layer was obtained $(100 \mu \mathrm{L})$ and diluted 40 times with $0.1 \%$ of sodium dodecyl sulphate (SDS) and the absorbance was recorded at $500 \mathrm{~nm}\left(A_{500}\right)$ using a UV-Vis spectrophotometer (Cary 50; Varian; CA, USA). The EAI was calculated using the following equation:

$$
\begin{aligned}
\tau & =\frac{2.303 \times A_{500} \times F}{l}, \\
\operatorname{EAI}\left(\mathrm{m}^{2} \mathrm{~g}^{2}\right) & =\frac{2 \tau}{\phi C},
\end{aligned}
$$

where $\tau$ is the turbidity, $A_{500}$ is the sample absorbance, $F$ is the sample dilution factor $(40)$, and $l(0.01 \mathrm{~m})$ is the light path length. The oil volume fractions for emulsions $(\phi)$ were 0.5 , and the protein emulsifier concentration $(C)$ was $0.5 \mathrm{mg} \mathrm{mL}^{-1}$.

To determine emulsifying stability index (ESI), aliquots of prepared emulsions $(10 \mathrm{~mL})$ were placed inside of $10 \mathrm{~mL}$ containers immediately after preparation. At 0 and $10 \mathrm{~min}$ following emulsion preparation, $100 \mu \mathrm{L}$ samples were removed and diluted 40 -fold prior to turbidity measurements. ESI was calculated from

$$
\operatorname{ESI}(\min )=\frac{\tau \times \Delta t}{\Delta \tau}
$$

where $\Delta \tau$ is the change in turbidity after a time interval $\Delta t$ (10 $\mathrm{min})$.

2.9. Foaming Properties. Foaming capacity (FC) and foam stability (FS) at different $\mathrm{pH}$ levels and $\mathrm{NaCl}$ concentrations were determined according to the Wild and Clark method [14] with some modifications. Each protein solution was adjusted to $2 \mathrm{mg} \mathrm{mL}^{-1}$. Twenty milliliters of diluted protein solutions was homogenized at $18000 \mathrm{rpm}$ for $1 \mathrm{~min}$ using a tissue homogenizer (Wisd; WiseTis HG-15D; Witeg, Germany). The solutions were transferred to a measuring cylinder. The volume of foam at $30 \mathrm{~s}$ was calculated, and the volume increase was expressed as percent foaming capacity (FC) and was calculated from

$$
\mathrm{FC}(\%)=\frac{\text { Volume of foam }(\mathrm{mL})}{\text { Initial liquid volume }(\mathrm{mL})} \times 100 \text {. }
$$

The foam stability (FS) was calculated as the percentage of foam remaining after $30 \mathrm{~min}$ at $25^{\circ} \mathrm{C}$, using the following equation:

$$
\text { FS (\%) }
$$

$$
\begin{aligned}
= & \frac{\text { Volume of foam }(\mathrm{mL}) \text { retained after } 30 \mathrm{~min}}{\text { Volume of foam soon after whipping }(\mathrm{mL})} \\
& \times 100
\end{aligned}
$$

2.10. Experimental Design and Statistical Analysis. A factorial experiment $(5 \times 3)$ was performed to determine the effects of individual factors and their interactions: ph with 5 levels and $\mathrm{NaCl}$ concentration with 3 . The response variables were protein solubility (\%), total sulfhydryl content (TSH, mole $10^{5} \mathrm{~g}^{-1}$ ), surface hydrophobicity ( $\mathrm{S}_{0}$-ANS and $\mathrm{S}_{0}$-PRODAN), emulsifying activity index (EAI, $\mathrm{m}^{2} \mathrm{~g}^{-1}$ ), emulsifying stability index (ESI, min), foaming capacity (FC, \%), and foam stability (FS, \%). All measurements were performed in triplicate, and data were presented as the mean \pm standard deviation. In order to determine the statistical differences among treatments, a two-way analysis of variance (ANOVA) was used to compare means with a significance level of $P<$ 0.05. Data were analyzed using the JMP statistical software version 10.0.0.

\section{Results and Discussion}

3.1. Sarcoplasmic Protein Recovery. The SP solution exhibited a protein concentration of $6.59 \pm 1.42 \mathrm{mg} \mathrm{mL}^{-1}$ and represented the $14.02 \pm 4.21 \%$ of total protein content from the mantle. The protein concentration of the SP extract was in the range obtained for Pacific whiting (Merluccius productus) surimi wash-water $\left(5.4-23.4 \mathrm{mg} \mathrm{mL}^{-1}\right)[15,16]$. This latter is one of the most utilized species for the manufacture of surimi (Rocha-Estrada et al., 2010). Regarding protein recovery, the SP fraction obtained in this study was lower than that obtained by Sánchez-Alonso et al. [17], who used a 1:5 (mantle: water) ratio for the extraction of sarcoplasmic proteins from jumbo squid mantle, reporting a protein recovery of 25-27\%, while De la Fuente-Betancourt et al. [18], who used a 1:10 (mantle: water) ratio, reported a recovery of $9.61 \%$, which is lesser than that obtained in this study. The recovery of SP fraction from jumbo squid mantle might be affected by factors related to protein extraction as the muscle/water ratio and the centrifugation conditions used [19]. Also, it might be affected by intrinsic (size and chemical composition) and extrinsic aspects (harvest season, temperature, and food availability) of the species [20].

3.2. Protein Solubility. Solubility is a critical functional property of proteins, because it is considered as prerequisite for other functionalities, including emulsifying and foaming properties. The effect of $\mathrm{pH}$ and $\mathrm{NaCl}$ concentration on the solubility of SP is shown in Figure 1. The solubility of SP in absence of $\mathrm{NaCl}$ showed the typical U-shaped curve as most food proteins, including marine sources [12]. The minimum and the maximum solubility of SP were presented at $\mathrm{pH}$ of 5 and 11, respectively. Hence, the isoelectric point (pI) of SP could be close to $\mathrm{pH}$ 5.0. The higher solubility of SP at alkaline $\mathrm{pH}$ in comparison to acid $\mathrm{pH}$ might be due to the amino acid ionization, unfolding, and hydration of protein. Most food proteins are acidic, since the sum of their acid residues (Asp and Glu) is higher than their basic residues (Lys, Arg, and His); therefore, proteins exhibit the minimal solubility at $\mathrm{pH}$ 4-5 (isoelectric $\mathrm{pH}$ ) and maximum at alkaline $\mathrm{pH}$ values [4]. In this sense, the presence of higher content of acid than basic residues in proteins from jumbo squid (Dosidicus gigas) 


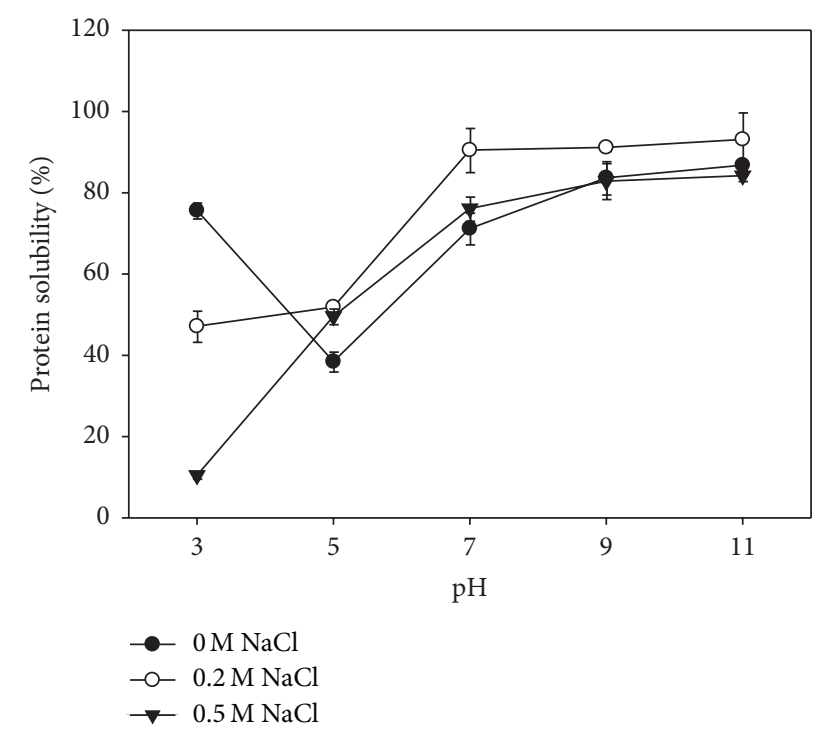

FIGURE 1: Effect of $\mathrm{pH}$ and $\mathrm{NaCl}$ concentration on protein solubility of SP from jumbo squid mantle. Data represent the mean \pm standard deviation $(n=3)$.

mantle has been reported, and this fact matches with the high solubility of SP obtained in this study at $\mathrm{pH}[21,22]$.

At alkaline $\mathrm{pH}$ the solubility was similar. However, at pH 3.0 the solubility was significantly different $(P<0.05)$. It was noted that the solubility was reduced when salt was added, obtaining the minimum with $0.5 \mathrm{M}$ of $\mathrm{NaCl}$. This behavior could be attributed to the interaction of negatively charged chloride ions $\left(\mathrm{Cl}^{-}\right)$with positively charged groups $\left(\mathrm{NH}^{3+}\right.$, from Lys, Arg, and His) of SP, leading to a decrease in electrostatic repulsion and subsequently leading to the aggregation and precipitation $[23,24]$. A similar phenomenon has been reported for myofibrillar proteins from Pacific whiting (Merluccius productus) and sarcoplasmic proteins from rockfish (Sebastes flavidus) [5,24].

3.3. Electrophoretic Profile (SDS-PAGE). In order to evaluate the effect of $\mathrm{pH}$ and $\mathrm{NaCl}$ concentration on the molecular weights (MW) of proteins present in sarcoplasmic fraction from squid mantle, electrophoretic profiles were determined. SDS-PAGE of the SP is shown in Figure 2. Protein bands with MW ranging from 30 to 63.7 were detected, and the corresponding bands $37.5,38.2$, and $44.3 \mathrm{kDa}$ were the most intense. When the $\mathrm{NaCl}$ was added to SP system, supernatants obtained at $\mathrm{pH} 5-11$ at all $\mathrm{NaCl}$ concentrations $(0,0.2$, and 0.5 ) did not show qualitative differences. The presence of weak bands at $\mathrm{pH} 3$ in $\mathrm{NaCl} 0.5 \mathrm{M}$ reaffirms the low protein solubility of SP at this condition. Based on solubility results and SDS-PAGE patterns, $\mathrm{NaCl}$ concentration appeared to have a negative effect on solubility of SP from jumbo squid mantle at extreme $\mathrm{pH}$. But SP from jumbo squid mantle became more soluble and stable at neutral and at alkaline values than at acid $\mathrm{pH}$ values.

The electrophoretic pattern obtained in this experiment was similar to that obtained by Ezquerra-Brauer et al. [20] for water-soluble proteins $(20-66 \mathrm{kDa})$ from jumbo squid mantle. However, De la Fuente-Betancourt et al. [18] obtained higher MW of SP from mantle of same species (20-97 kDa). As described earlier, the recovery of SP fraction might be affected by intrinsic and extrinsic factors of jumbo squid, as well as by extraction conditions used $[19,25]$.

The proteins present in sarcoplasmic fraction from fish species are related to aerobic metabolism of the fish cells and have exhibited MW of $34,40,43,50$, and $94 \mathrm{kDa}$, which were attributed to glyceraldehyde phosphate dehydrogenase, aldolase, creatine kinase, enolase, and phosphorylase, respectively $[3,12,26,27]$. Nevertheless, since jumbo squid is a mollusk, it has a quite different SP profile compared to fish species; activity of arginine kinase $(40-43 \mathrm{kDa})$ and octopine dehydrogenase (37-45 kDa) has been reported [28-31]. These are enzymes related to the anaerobic metabolism of mollusks and exhibit MW similar to that obtained in this study for SP fraction from jumbo squid mantle. However, in order to know more about the protein components of SP, further research related to protein characterization is required.

3.4. Total Sulfhydryl (SH) Content. Conformational changes of proteins can lead to the exchange of SH/S-S. Thus, total SH content is an indicator of changes in protein conformation and flexibility $[20,21]$. Total sulfhydryl (TSH) content of SP varied significantly with $\mathrm{pH}$ and $\mathrm{NaCl}$ concentration $(P<0.05)$ (Figure 3). The TSH content decreased when $\mathrm{pH}$ was changed from 5 to 11 and from 5 to 3 ; the effect was more pronounced as the $\mathrm{NaCl}$ concentration increased. The unfolding of SP induced by $\mathrm{pH}$ shift (at both acidic and alkaline $\mathrm{pH}$ values) might have induced the exposition of buried $\mathrm{SH}$ groups and the consequent S-S formation. It was reported that exchange reactions $\mathrm{SH} / \mathrm{S}-\mathrm{S}$ are favored at alkaline $\mathrm{pH}[32,33]$. The results of $\mathrm{SH}$ content demonstrated that at extreme $\mathrm{pH}(\mathrm{pH} 3$ and $\mathrm{pH} 11)$ the $\mathrm{SH}$ oxidation of SP was induced. Similar findings for myofibrillar proteins from Pacific whiting (Merluccius productus) and sarcoplasmic proteins from striped catfish (Pangasius hypophthalmus) have been reported [11,34]. On the other hand, the decrease of TSH content by $\mathrm{NaCl}$ effect can be attributed to a better protein unfolding, with the consequent exposition of intern functional groups, including the SH groups $[22,35]$. The major exposition of $\mathrm{SH}$ groups might have allowed the exchange of SH to S-S.

3.5. Surface Hydrophobicity $\left(S_{0}\right)$. Variations on surface hydrophobicity $\left(\mathrm{S}_{0}\right)$ denote changes in protein structure/ conformation. In this study, surface hydrophobicity of SP was determined at different $\mathrm{pH}$ levels and $\mathrm{NaCl}$ concentrations, based on ANS and PRODAN probes. Surface hydrophobicity based on the ANS probe ( $\mathrm{S}_{0}$-ANS) was significantly affected by $\mathrm{pH}$ and $\mathrm{NaCl}$ concentration $(P<0.05)$ (Figure $4(\mathrm{a})$ ). Extremely high values of $\mathrm{S}_{0}$-ANS were obtained at $\mathrm{pH} 3$ compared to $\mathrm{S}_{0}$-PRODAN values. It has been reported that at acidic $\mathrm{pH}$ values (minor to $\mathrm{pH}$ 3.8) $\mathrm{S}_{0}$-ANS reflects not only the hydrophobic interaction between ANS and proteins, but also electrostatic interactions between anionic sulfonate groups of ANS and cationic groups (Lys, Arg, and His) 


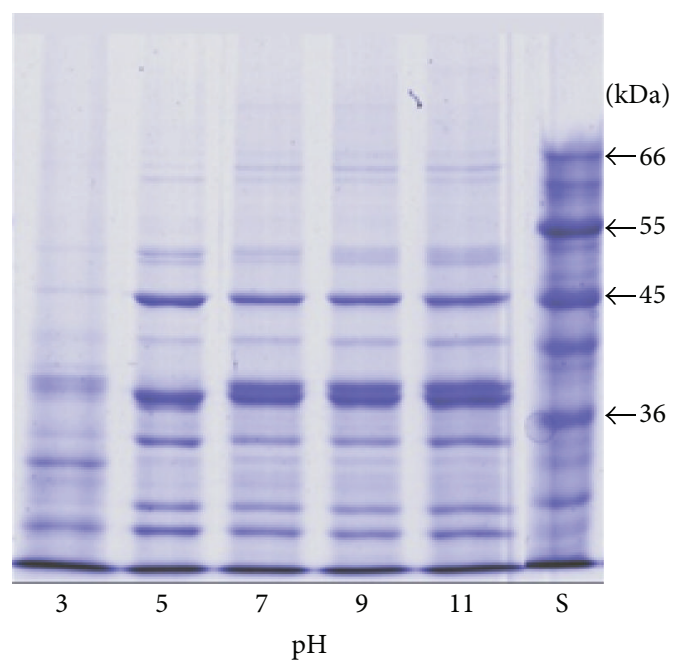

(a)

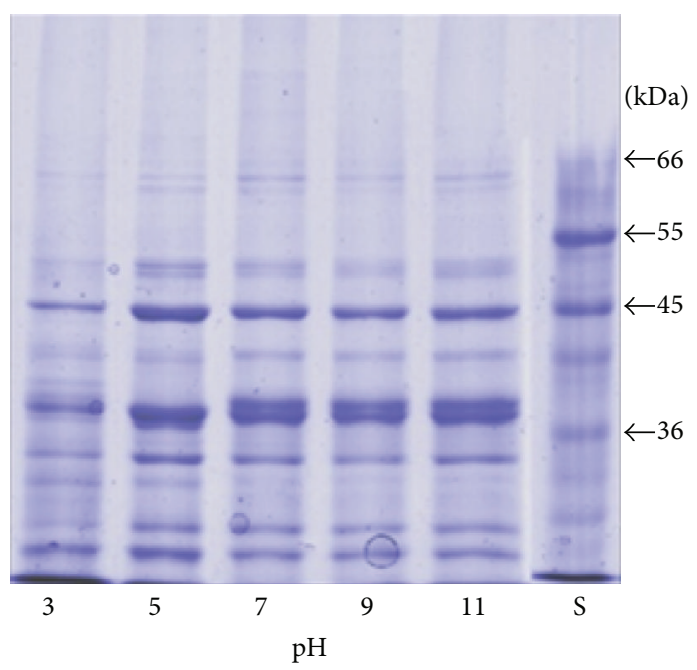

(b)

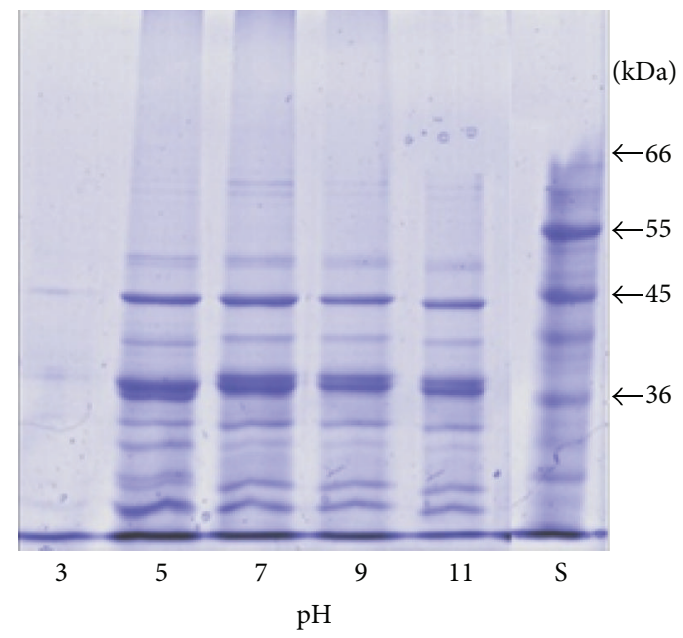

(c)

Figure 2: Protein patterns of SP from jumbo squid in (a) $0 \mathrm{M} \mathrm{NaCl}$, (b) $0.2 \mathrm{M} \mathrm{NaCl}$, and (c) $0.5 \mathrm{M} \mathrm{NaCl}$. The numbers indicate pH while $\mathrm{S}$ denotes molecular weight standard.

of proteins [10]. Other research works reported the same behavior of ANS at acidic $\mathrm{pH}$ values [11, 34]. Therefore, in this experiment, the change of surface hydrophobicity is discussed with more detail in function of PRODAN reagent.

$\mathrm{S}_{0}$-PRODAN was also significantly affected by $\mathrm{pH}$ and $\mathrm{NaCl}$ concentrations $(P<0.05)$ (Figure 4(b)). The $\mathrm{S}_{0^{-}}$ PRODAN values of $\mathrm{SP}$ in absence of $\mathrm{NaCl}$ increased as the $\mathrm{pH}$ increased in the range from 5 to 11 . The high $\mathrm{S}_{0^{-}}$ PRODAN values at alkaline $\mathrm{pH}$ (11) were attributed to a higher exposure of buried hydrophobic groups due to the electrostatic repulsion of negative charged residues. In contrast, at $\mathrm{pH} 5$, the minimum $\mathrm{S}_{0}$-PRODAN value was showed, and this might be due to the protein aggregation, because at this $\mathrm{pH}$ the minimum solubility was detected, leading to a lower surface hydrophobicity of SP. These results agree with those obtained for myofibrillar proteins from Pacific whiting (Merluccius productus), sarcoplasmic proteins from striped catfish (Pangasius hypophthalmus), and threadfin bream (Nemipterus sp.) $[6,11,34]$.
It was proved that a positive correlation exists between solubility and surface hydrophobicity of SP, being highly significant with $r^{2}$ of $0.82,0.91$, and 0.96 for $0.0,0.2$, and $0.5 \mathrm{M}$ of $\mathrm{NaCl}$, respectively. This could be explained as a function of the unfolding of SP induced by $\mathrm{pH}$ and $\mathrm{NaCl}$ modification and the consequent increase of both solubility and surface hydrophobicity. The effect of $\mathrm{NaCl}$ concentration at $\mathrm{pH} 3$ was opposite in comparison to other $\mathrm{pH}$ values; however, this behavior was the same as the solubility, and it could be due to the decrease of hydrophobic groups exposed for the SP aggregation, as already explained for SP solubility.

3.6. Emulsifying Properties. The effects of $\mathrm{pH}$ and $\mathrm{NaCl}$ concentration on emulsifying activity index (EAI) and emulsifying stability index (ESI) are shown in Figure 5. The EAI value of crude extract of $\mathrm{SP}(\mathrm{pH} 7,0 \mathrm{M} \mathrm{NaCl})$ obtained in this study $\left(83.32 \pm 1.59 \mathrm{~m}^{2} \mathrm{~g}^{-1}\right)$ was lower than that obtained for sarcoplasmic proteins from threadfin bream (Nemipterus sp.) 


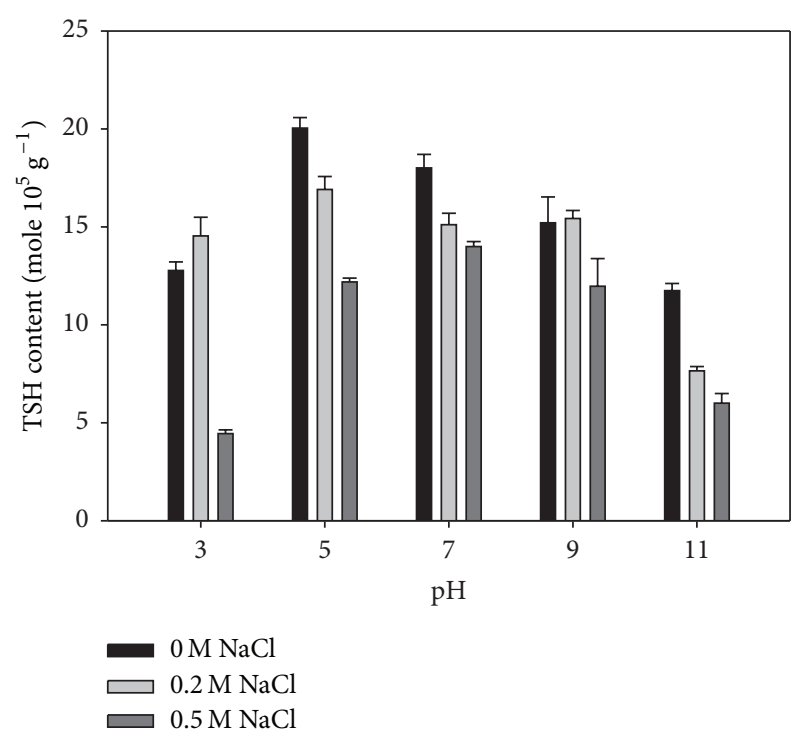

FIgURE 3: Effect of $\mathrm{pH}$ and $\mathrm{NaCl}$ concentration on total sulfhydryl (TSH) content in SP from jumbo squid mantle. Data represent the mean \pm standard deviation $(n=3)$.

$\left(\sim 210 \mathrm{~m}^{2} \mathrm{~g}^{-1}\right)$ [6]. However, this was higher than that reported for lyophilized sarcoplasmic proteins from threadfin bream (Nemipterus hexodon), because an EAI of $46 \mathrm{~m}^{2} \mathrm{~g}^{-1}$ has been reported [6].

Figure 5(a) shows the EAI for $\mathrm{SP}$ as a function of $\mathrm{pH}$ and $\mathrm{NaCl}$ concentration. EAI of SP was significantly affected by the $\mathrm{pH}$ and $\mathrm{NaCl}$ concentration $(P<0.05)$, showing the minimum value at $\mathrm{pH} 5$ and the higher at $\mathrm{pH}$ 11. Since $\mathrm{pH} 5$ is closer to the isoelectric point, the low EAI was presented due to aggregation and loss of solubility of SP, as a result of the minimum electrostatic repulsion [24]. Yongsawatdigul and Hemung [26] also found that EAI of emulsion stabilized by sarcoplasmic proteins of threadfin bream (Nemipterus sp.) was lowest at its $\mathrm{pI}(\mathrm{pH} 5)$.

At $\mathrm{pH} 5$, the increase in EAI could be due to increase in solubility, caused by the addition of $\mathrm{NaCl}$. At $\mathrm{pH}$ lower or higher than 5 the EAI increase can be due to a major solubility. It was noted that, at $\mathrm{pH}$ lower or higher than 5 , the EAI changes very little; it remains practically unchanged, with $\mathrm{pH} 11$ in absence of $\mathrm{NaCl}$ as exception. Kristinsson and Hultin [16] also found that EAI of emulsion stabilized by myofibrillar proteins from cod (Gadus morhua) was higher at $\mathrm{pH} 11$, and this result was well correlated with the increase of surface hydrophobicity and interfacial activity. In contrast, Hemung et al. [8] found that EAI of emulsion stabilized by sarcoplasmic proteins from threadfin bream (Nemipterus sp.) was higher at $\mathrm{pH} 3\left(610 \mathrm{~m}^{2} \mathrm{~g}^{-1}\right)$ than at $\mathrm{pH} 12\left(363 \mathrm{~m}^{2} \mathrm{~g}^{-1}\right)$, and these results were not correlated with $\mathrm{S}_{0}$-PRODAN values. Hence, it can be mentioned that the EAI of proteins is species dependent.

The addition of $\mathrm{NaCl}$ to the $\mathrm{SP}$ system at $\mathrm{pH} 11$ decreases the EAI, which could be related to the increase of hydrophobic groups exposed $\left(\mathrm{S}_{0}\right.$-PRODAN) and the decrease in solubility with the increase of $\mathrm{NaCl}$ concentration, indicating that the hydrophobic/hydrophilic balance of SP was affected. This balance is necessary because proteins have to interact with both oil and water; thus, the high exposition of hydrophobic groups and the possible major rigidity of SP by the disulfide bonds (S-S) formation could have induced the decrease of EAI of emulsion at $\mathrm{pH}$ 11. Yuliana et al. [36] also found that EAI of emulsion stabilized by proteins isolated from cashew nut shell (Cashew variety Venguria4) was decreasing with the increase of $\mathrm{NaCl}$ concentration (0-2 M). In contrast, Zhang et al. [37] found that EAI of emulsion stabilized by protein concentrate from chickpea (Cicer arietinum L.) was increased with the increase of $\mathrm{NaCl}$ concentration $(0-1 \mathrm{M})$, which was correlated with the increase of hydrophobicity.

The ESI value of crude extract of SP (pH 7) obtained in this study was $73.12 \pm 14.57 \mathrm{~min}$. This value was higher than those reported for sarcoplasmic proteins from rohu (Labeo rohita, $52 \mathrm{~min}$ ) and from threadfin bream (Nemipterus hexodon, $63 \mathrm{~min}$ ) $[8,38]$. Figure $5(\mathrm{~b})$ shows ESI values for $\mathrm{SP}$ as a function of $\mathrm{pH}$ and $\mathrm{NaCl}$ concentration. ESI was significantly affected by the $\mathrm{pH}$ and $\mathrm{NaCl}$ concentration $(P<$ 0.05). The graph indicates that as $\mathrm{pH}$ increases ESI increased independently of the $\mathrm{NaCl}$ concentration, being significantly higher at $\mathrm{pH}$ 11. The minimum ESI value was at $\mathrm{pH} 3$ in the absence of $\mathrm{NaCl}$, whereas the maximum value was reached at $\mathrm{pH} 11$ in presence of $0.5 \mathrm{M} \mathrm{NaCl}$. The increase of ESI at $\mathrm{pH}$ 11 regarding SP at pH 7 was $243.31 \%$. This might be due to the large repulsion, which prevents the coalesce [39]. At pH 11 and $0.5 \mathrm{M}$ of $\mathrm{NaCl}$ the highest surface hydrophobicity and the lowest $\mathrm{SH}$ content were present, the latter indicating that the major disulfide (S-S) bonds formation occurred under these conditions. Therefore, the SP, once absorbed, might stabilize interactions between proteins that form the interface $[15,40]$.

3.7. Foaming Properties. The effects of $\mathrm{pH}$ and $\mathrm{NaCl}$ concentration on foaming capacity (FC) and foam stability (FS) are shown in Figures 6(a) and 6(b), respectively. The FC value of crude extract of SP (pH 7, $0 \mathrm{M} \mathrm{NaCl}$ ) obtained in this study was $57.5 \pm 2.5 \%$. This value was higher than that reported for sarcoplasmic proteins from rohu (Labeo rohita, 41.33\%) using a solution with a protein concentration of $2.5 \mathrm{mg} \mathrm{mL}^{-1}$, similar to the one used in this study $\left(2 \mathrm{mg} \mathrm{mL}^{-1}\right)$ [38], and was lower than that reported for sarcoplasmic proteins from threadfin bream (Nemipterus hexodon, 165\%) [6].

The FC of SP was significantly affected by the $\mathrm{pH}$ and $\mathrm{NaCl}$ concentration $(P<0.05)$ (Figure 6(a)). The behavior of $\mathrm{FC}$ as a function of $\mathrm{pH}$ showed a similar tendency as EAI. In absence of $\mathrm{NaCl}$, the $\mathrm{FC}$ was found to be the lowest at $\mathrm{pH}$ $5(24.11 \pm 3.65 \%)$ and the highest at $\mathrm{pH} 11(87.84 \pm 1.25 \%)$. At $\mathrm{pH} 5$, the low FC could be related to low solubility due to the fact that at this $\mathrm{pH}$ low electrostatic repulsion occurs causing formation of aggregates and precipitation, affecting its interfacial activity $[5,12]$. The highest FC at $\mathrm{pH} 11$ could be related, as well as EAI, to the high protein solubility and hydrophobicity of SP. Krasaechol et al. [6] reported that the FC and FS are related to a high hydrophobicity. Yet, the results 


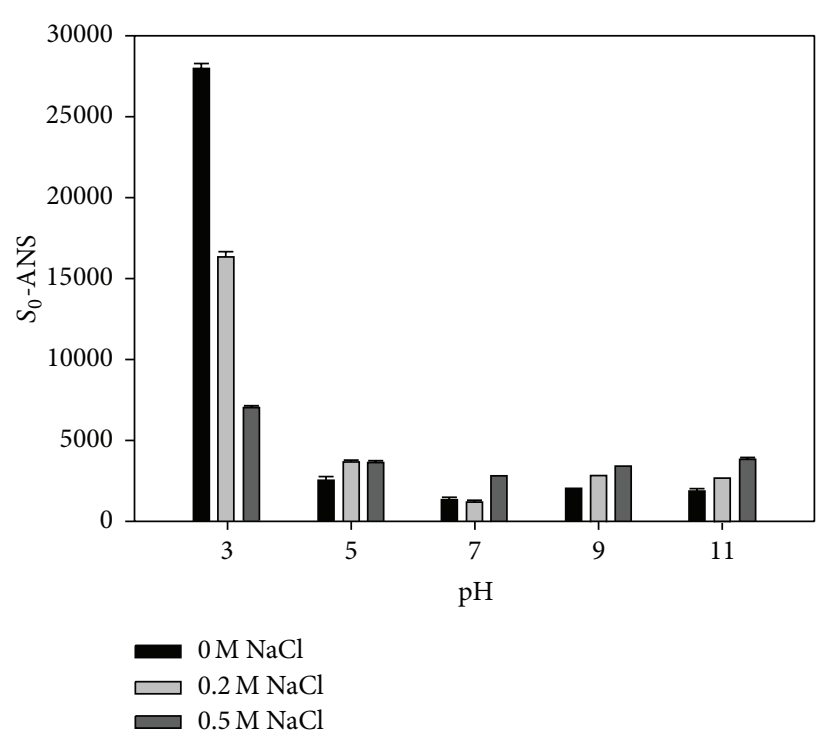

(a)

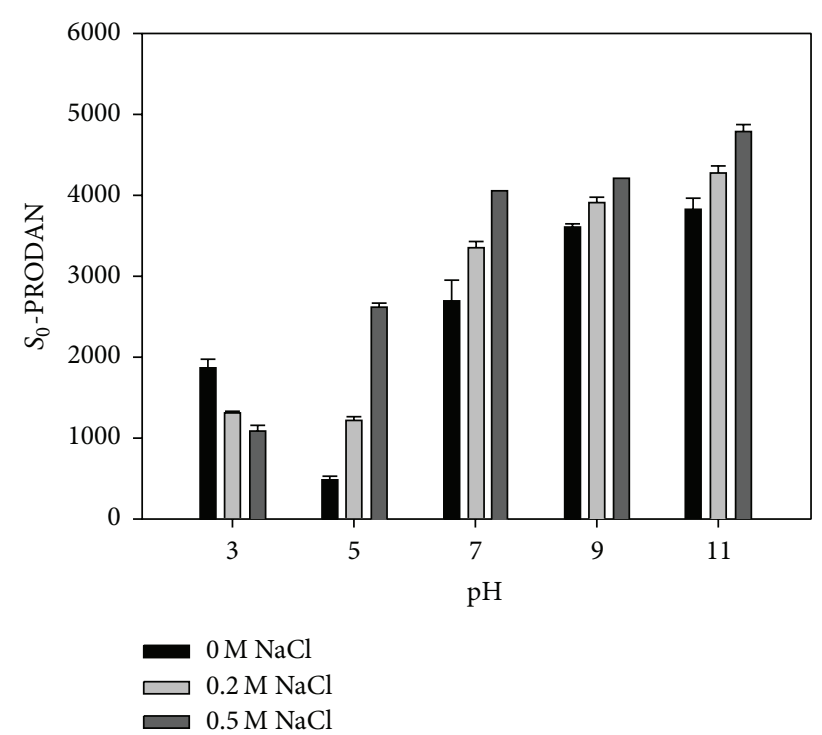

(b)

FIGURE 4: Effect of $\mathrm{pH}$ and $\mathrm{NaCl}$ concentration on the surface hydrophobicity $\left(\mathrm{S}_{0}\right)$ in SP from jumbo squid mantle, using the probes (a) ANS and (b) PRODAN. Data represent the mean \pm standard deviation $(n=3)$.

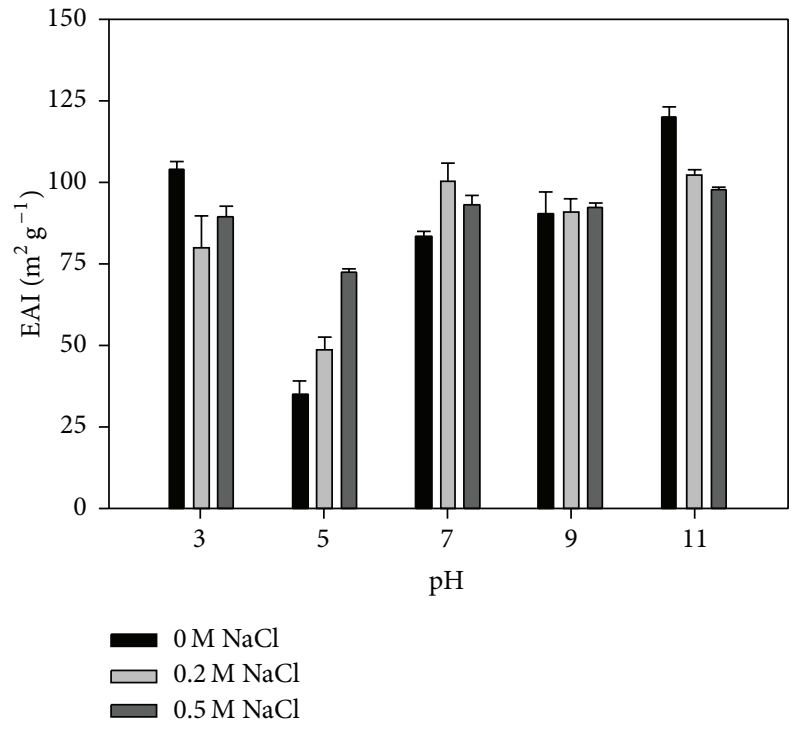

(a)

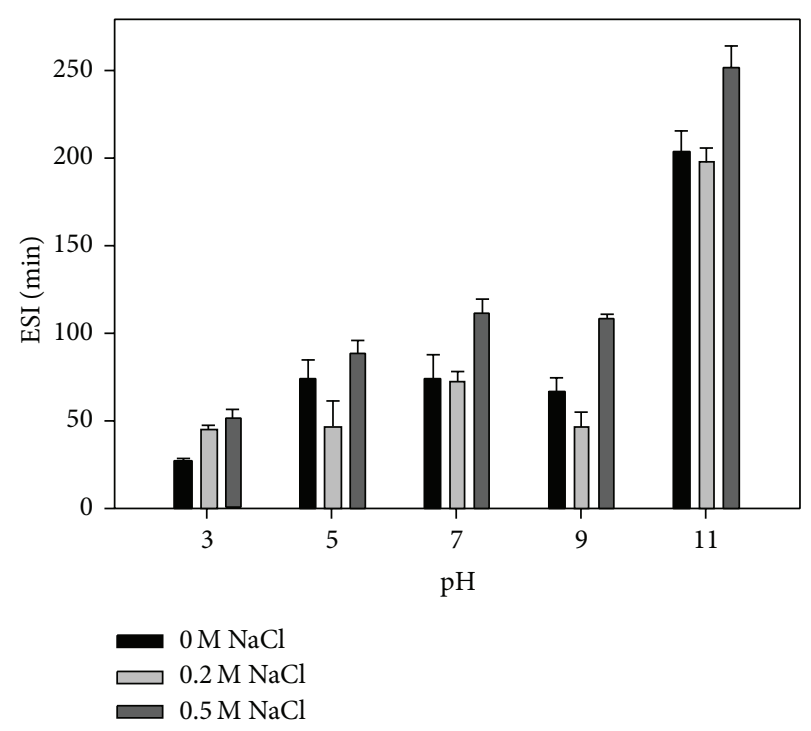

(b)

FIGURE 5: Effect of $\mathrm{pH}$ and $\mathrm{NaCl}$ concentration on (a) emulsifying activity index (EAI) and (b) emulsifying stability index (ESI) of SP from jumbo squid mantle. Data represent the mean \pm standard deviation $(n=3)$.

obtained for FC, in function of $\mathrm{pH}$, did not correlate well with surface hydrophobicity and solubility of SP.

As well as the emulsifying properties, foaming properties of food proteins also are better at $\mathrm{pH}$ values away from their isoelectric point ( $\mathrm{pI})$, especially at alkaline $\mathrm{pH}$ values. Similar results have been found by Rocha-Estrada et al. [41] and Galvez-Rongel et al. [42]; this research found better FC values for proteins from jumbo squid (Dosidicus gigas) mantle treated at alkaline $\mathrm{pH}$ values [3].
The increment of $\mathrm{NaCl}$ concentration decreased the FC values to $\mathrm{pH} 11$, possible due to the higher exposition of hydrophobic groups and decrease of solubility, with the consequent change of hydrophobicity/hydrophobicity balance of the SP, as occurred in EAI. Rocha-Estrada et al. [41] found that the FC of foams stabilized by proteins from jumbo squid (Dosidicus gigas) decreased with the increase of $\mathrm{NaCl}$ concentration $(0-0.4 \mathrm{M})$. Yuliana et al. [36] also found that FC stabilized by proteins isolated from cashew nut shell 


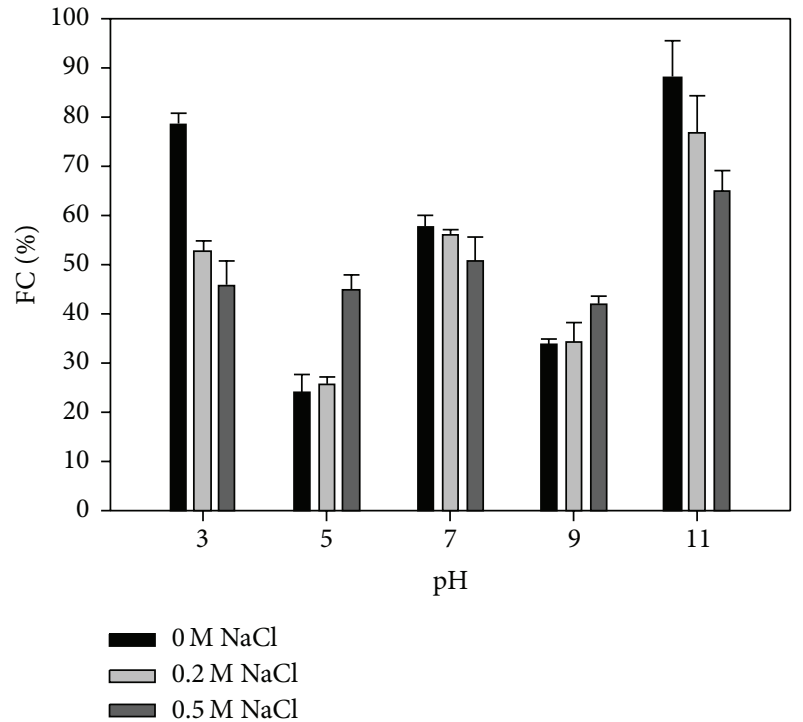

(a)

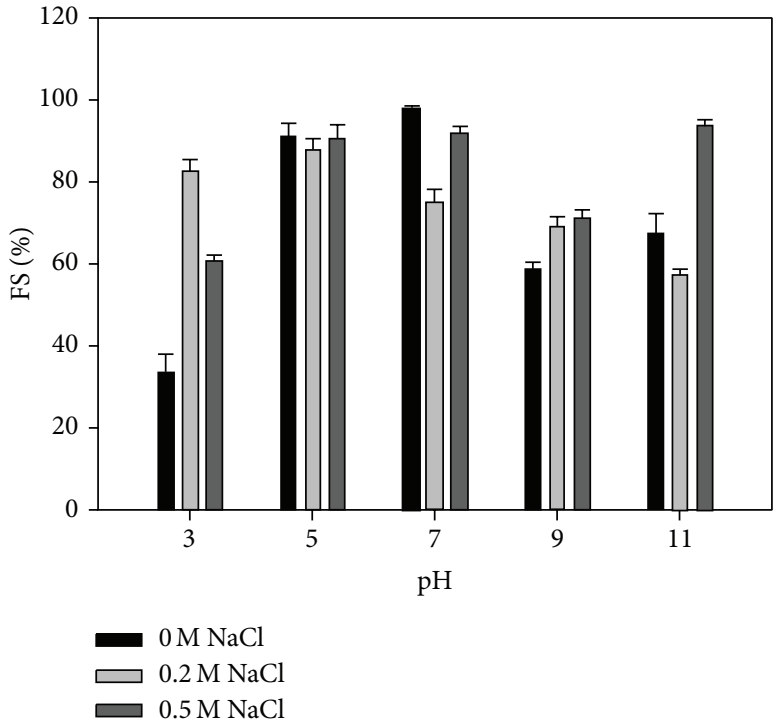

(b)

Figure 6: Effect of $\mathrm{pH}$ and $\mathrm{NaCl}$ concentration on (a) foaming capacity (FC) and (b) foam stability (FS) of SP from jumbo squid mantle. Data represent the mean \pm standard deviation $(n=3)$.

(Cashew variety Venguria-4) decreased with the increase of $\mathrm{NaCl}$ concentration $(0-2 \mathrm{M})$.

Figure 6(b) shows the results of FS $(P<0.05)$. It was detected that FS was affected by the $\mathrm{pH}$ and did not follow the obtained tendency of the other functional properties (EAI, ESI, and FC). Furthermore, all $\mathrm{pH}$ values presented irregular $\mathrm{FS}$ values in function of $\mathrm{NaCl}$ concentration. In $\mathrm{NaCl}$ absence, FS was found to be the lowest at $\mathrm{pH} 3(33.2 \pm$ $5.02 \%)$ and the highest at $\mathrm{pH} 7(97.76 \pm 0.85 \%)$. No significant differences $(P<0.05)$ were found at $\mathrm{pH} 5$ by effect of $\mathrm{NaCl}$ concentrations. The best results were obtained at $\mathrm{pH} 5$ and $\mathrm{pH} \mathrm{7}$; at higher or lower $\mathrm{pH}$ values the tendency was to decrease. This indicates that $\mathrm{pH} 7$ could be the best option to make foams. Our results differ from those obtained by RochaEstrada et al. [41] who working with myofibrillar proteins from jumbo squid (Dosidicus gigas) reported that alkaline $\mathrm{pH}$ values (10-12) presented the highest FS values, when $\mathrm{NaCl}$ was added $(0-0.4 \mathrm{M})$. Nonetheless, many studies have shown that stability is better at $\mathrm{pH}$ close to $\mathrm{pI}$. With $\mathrm{pH}$ values near to $\mathrm{pI}$, the absence of repulsive interactions between proteins promotes attractive interactions. Thus, it promotes the formation of a viscoelastic layer in the interface air/water [15].

\section{Conclusions}

Conformational changes of sarcoplasmic proteins from jumbo squid mantle were influenced by $\mathrm{pH}$ and $\mathrm{NaCl}$ concentration and, consequently, their functional properties. Proteins presented the highest solubility and hydrophobicity in absence of $\mathrm{NaCl}$ at $\mathrm{pH} 11$ resulting in an increase of emulsifying and foaming capacity. The emulsifying stability was better at $\mathrm{pH} 11$ and was enhanced by the increase of $\mathrm{NaCl}$, due to the hydrophobic interactions on interface oil/water. However, foaming stability was enhanced by the absence of electrostatic repulsions at $\mathrm{pH}$ near to $\mathrm{pI}$. These proteins have shown that they could be used as food ingredients and their functional properties can be improved by changing $\mathrm{pH}$ and/or $\mathrm{NaCl}$ concentration, thus contributing to a better use of this fishery resource.

\section{Conflict of Interests}

The authors declare that they have no conflict of interests.

\section{References}

[1] M. C. Luna-Raya, J. I. Urciaga-García, C. A. Salinas-Zabala, M. A. Cisneros-Mata, and L. F. Beltrán-Morales, "Diagnóstico del consumo del calamar gigante en México y en Sonora," Economía Sociedad y Territorio, vol. 6, pp. 535-560, 2006.

[2] J. W. Park and M. T. Morrissey, "Manufacturing and Surimi from light muscle fish," in Surimi and Surimi Seafood, J. W. Park, Ed., pp. 23-58, Marcel Dekker Inc, New York, NY, USA; CRC Press, Basel, Switzerland, 2000.

[3] T. Nakagawa, S. Watabe, and K. Hashimoto, "Identification of three major components in fish sarcoplasmic proteins," Nippon Suisan Gakkaishi, vol. 54, no. 6, pp. 999-1004, 1998.

[4] Y. S. Kim, J. W. Park, and Y. J. Choi, "New approaches for the effective recovery of fish proteins and their physicochemical characteristics," Fisheries Science, vol. 69, no. 6, pp. 1231-1239, 2003.

[5] Y. S. Kim, J. Yongsawatdigul, J. W. Park, and S. Thawornchinsombut, "Characteristics of sarcoplasmic proteins and their interaction with myofibrillar proteins," Journal of Food Biochemistry, vol. 29, no. 5, pp. 517-532, 2005. 
[6] N. Krasaechol, R. Sanguandeekul, K. Duangmal, and R. K. Owusu-Apenten, "Structure and functional properties of modified threadfin bream sarcoplasmic protein," Food Chemistry, vol. 107, no. 1, pp. 1-10, 2008.

[7] Y. Kawai, R. Ohno, N. Inoue, and H. Shinano, "Emulsifying activity of heat treated sarcoplasmic protein from sardine," Fisheries Science, vol. 61, pp. 852-855, 1995.

[8] B.-O. Hemung, S. Benjakul, and J. Yongsawatdigul, “pHdependent characteristics of gel-like emulsion stabilized by threadfin bream sarcoplasmic proteins," Food Hydrocolloids, vol. 30, no. 1, pp. 315-322, 2013.

[9] O. H. Lowry, N. J. Rosebrough, A. L. Farr, and R. J. Randall, "Protein measurement with the Folin phenol reagent," Journal of Biological Chemistry, vol. 193, no. 1, pp. 265-275, 1951.

[10] U. K. Laemmli, "Cleavage of structural proteins during the assembly of the head of bacteriophage T4," Nature, vol. 227, no. 5259, pp. 680-685, 1970.

[11] N. Alizadeh-Pasdar and E. C. Y. Li-Chan, "Comparison of protein surface hydrophobicity measured at various $\mathrm{pH}$ values using three different fluorescent probes," Journal of Agricultural and Food Chemistry, vol. 48, no. 2, pp. 328-334, 2000.

[12] P. Tadpitchayangkoon, J. W. Park, and J. Yongsawatdigul, "Conformational changes and dynamic rheological properties of fish sarcoplasmic proteins treated at various pHs," Food Chemistry, vol. 121, no. 4, pp. 1046-1052, 2010.

[13] K. N. Pearce and J. E. Kinsella, "Emulsifying properties of proteins: evaluation of a turbidimetric technique," Journal of Agricultural and Food Chemistry, vol. 26, no. 3, pp. 716-723, 1978.

[14] P. J. Wild and D. C. Clark, "Foam formation and stability," in Methods for Testing Protein Functionality, G. M. Hall, Ed., pp. 110-148, Blackie Academic and Professional, London, UK, 1996.

[15] S. Damodaran, "Aminoacids, peptides, and proteins," in Food Chemistry, S. Damodaran, K. L. Parkin, and O. R. Fennema, Eds., pp. 217-330, CRC Press, Boca Raton, Fla, USA, 2008.

[16] H. G. Kristinsson and H. O. Hultin, "Effect of low and high pH treatment on the functional properties of cod muscle proteins," Journal of Agricultural and Food Chemistry, vol. 51, no. 17, pp. 5103-5110, 2003.

[17] I. Sánchez-Alonso, M. Careche, and A. J. Borderías, "Method for producing a functional protein concentrate from giant squid (Dosidicus gigas) muscle," Food Chemistry, vol. 100, no. 1, pp. 4854, 2007.

[18] G. De la Fuente-Betancourt, F. García-Carreño, M. V. Navarrete-del Toro, R. Pacheco-Aguilar, and J. H. CórdovaMurueta, "Effect of storage at $0^{\circ} \mathrm{C}$ on mantle proteins and functional properties of jumbo squid," International Journal of Food Science and Technology, vol. 43, no. 7, pp. 1263-1270, 2008.

[19] J. W. Park and T. M. Lin, "Surimi: manufacturing and evaluation," in Surimi and Surimi Seafood, J. W. Park, Ed., pp. 35-98, CRC Press, Boca Raton, Fla, USA, 2005.

[20] J. M. Ezquerra-Brauer, N. F. Haard, R. Ramírez-Olivas, H. Olivas-Burrola, and C. J. Velázquez-Sánchez, "Influence of harvest season on the proteolytic activity of hepatopancreas and mantle tissues from jumbo squid (Dosidicus gigas)," Journal of Food Biochemistry, vol. 26, no. 5, pp. 459-475, 2002.

[21] J. H. Córdova-Murueta and F. L. García-Carreño, "Nutritive value of squid and hydrolyzed protein supplement in shrimp feed," Aquaculture, vol. 210, no. 1-4, pp. 371-384, 2002.

[22] N. Rajapakse, E. Mendis, H.-G. Byun, and S.-K. Kim, "Purification and in vitro antioxidative effects of giant squid muscle peptides on free radical-mediated oxidative systems," Journal of Nutritional Biochemistry, vol. 16, no. 9, pp. 562-569, 2005.

[23] D. C. A. Mireles, J. T. M. Lin, and A. Ismond, "Waste management, utilization, and challenges," in Surimi and Surimi Seafood, J. W. Park, Ed., pp. 313-339, CRC Press, New York, NY, USA, 2013.

[24] S. Thawornchinsombut and J. W. Park, "Role of $\mathrm{pH}$ in solubility and conformational changes of Pacific whiting muscle proteins," Journal of Food Biochemistry, vol. 28, no. 2, pp. 135-154, 2004.

[25] M. Lin, J. W. Park, and M. T. Morrissey, "Recovered protein and reconditioned water from surimi processing waste," Journal of Food Science, vol. 50, no. 1, pp. 4-9, 1995.

[26] J. Yongsawatdigul and B.-O. Hemung, "Structural changes and functional properties of threadfin bream sarcoplasmic proteins subjected to $\mathrm{pH}$-shifting treatments and lyophilization," Journal of Food Science, vol. 75, no. 3, pp. C251-C257, 2010.

[27] M. Toyohara, M. Murata, M. Ando, S. Kubota, M. Sakaguchi, and H. Toyohara, "Texture changes associated with insolubilization of sarcoplasmic proteins during salt-vinegar curing of fish," Journal of Food Science, vol. 64, no. 5, pp. 804-807, 1999.

[28] J. L. Schrimsher and K. B. Taylor, "Octopine dehydrogenase from Pecten maximus: steady-state mechanism," Biochemistry, vol. 23, no. 7, pp. 1348-1353, 1984.

[29] G. Gäde and K.-H. Carlsson, "Purification and characterisation of octopine dehydrogenase from the marine nemertean Cerebratulus lacteus (Anopla: Heteronemerta): comparison with scallop octopine dehydrogenase," Marine Biology, vol. 79, no. 1, pp. 39-45, 1984.

[30] A. E. Brown, R. M. France, and S. H. Grossman, "Purification and characterization of arginine kinase from the American cockroach (Periplaneta americana)," Archives of Insect Biochemistry and Physiology, vol. 56, no. 2, pp. 51-60, 2004.

[31] E. Maárquez-Riáos, E. F. Moraán-Palacio, M. E. Lugo-Saánchez, V. M. Ocano-Higuera, and R. Pacheco-Aguilar, "Postmortem biochemical behavior of giant squid (Dosidicus gigas) mantle muscle stored in ice and its relation with quality parameters," Journal of Food Science, vol. 72, no. 7, pp. C356-C362, 2007.

[32] J. Yongsawatdigul and J. W. Park, "Effect of alkaline and acid solubilization on gelation characteristics of rockfish proteins," Fisheries Science, vol. 69, pp. 499-505, 2004.

[33] J. Kijowski, "Muscle proteins," in Chemical and Functional Properties of Food Proteins, Z. E. Sirkorski, Ed., pp. 233-270, CRC Press, Lancaster, Pa, USA, 2001.

[34] C. A. M. DeWitt, G. Gomez, and J. M. James, "Protein extraction from beef heart using acid solubilization," Journal of Food Science, vol. 67, no. 9, pp. 3335-3341, 2002.

[35] S. Nakai and E. Li-Chan, Hydrophobic Interactions in Food Systems, CRC Press, Boca Raton, Fla, USA, 1988.

[36] M. Yuliana, C. T. Truong, L. H. Huynh, Q. P. Ho, and Y.-H. Ju, "Isolation and characterization of protein isolated from defatted cashew nut shell: influence of $\mathrm{pH}$ and $\mathrm{NaCl}$ on solubility and functional properties," LWT-Food Science and Technology, vol. 55, no. 2, pp. 621-626, 2014.

[37] T. Zhang, B. Jiang, W. Mu, and Z. Wang, "Emulsifying properties of chickpea protein isolates: influence of $\mathrm{pH}$ and $\mathrm{NaCl}$," Food Hydrocolloids, vol. 23, no. 1, pp. 146-152, 2009.

[38] F. J. Monahan, J. B. German, and J. E. Kinsella, "Effect of $\mathrm{pH}$ and temperature on protein unfolding and thiol/disulfide interchange reactions during heat-induced gelation of whey proteins," Journal of Agricultural and Food Chemistry, vol. 43, no. 1, pp. 46-52, 1995. 
[39] D. J. McClements, Food Emulsions: Principles, Practices, and Techniques, CRC Press, Boca Raton, Fla, USA, 2005.

[40] S. Tcholakova, N. D. Denkov, I. B. Ivanov, and B. Campbell, "Coalescence in $\beta$-lactoglobulin-stabilized emulsions: effects of protein adsorption and drop size," Langmuir, vol. 18, no. 23, pp. 8960-8971, 2002.

[41] J. G. Rocha-Estrada, J. H. Córdova-Murueta, and F. L. GarcíaCarreno, "Functional properties of protein from frozen mantle and fin of jumbo squid Dosidicus gigas in function of $\mathrm{pH}$ and ionic strength," Food Science and Technology International, vol. 16, no. 5, pp. 451-458, 2010.

[42] A. Galvez-Rongel, J. M. Ezquerra-Brauer, V. M. Ocano-Higuera et al., "Methods to obtain protein concentrates from jumbo squid (Dosidicus gigas) and evaluation of their functionality," Food Science and Technology International, vol. 20, no. 2, pp. 109-117, 2014. 

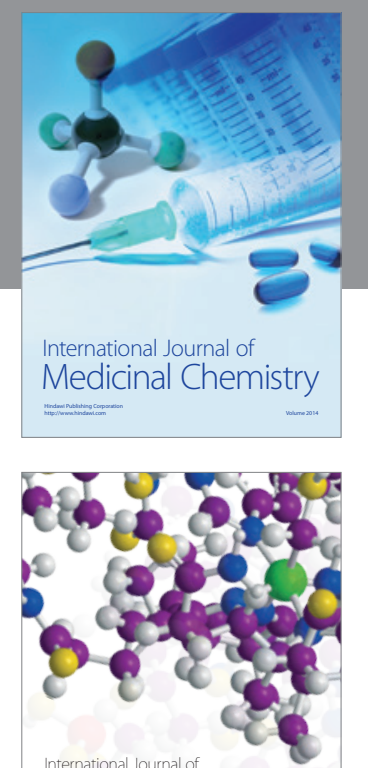

\section{Carbohydrate} Chemistry

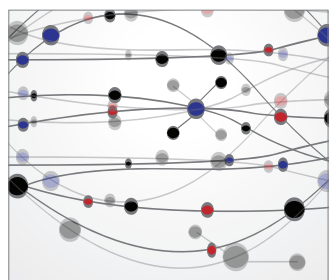

The Scientific World Journal
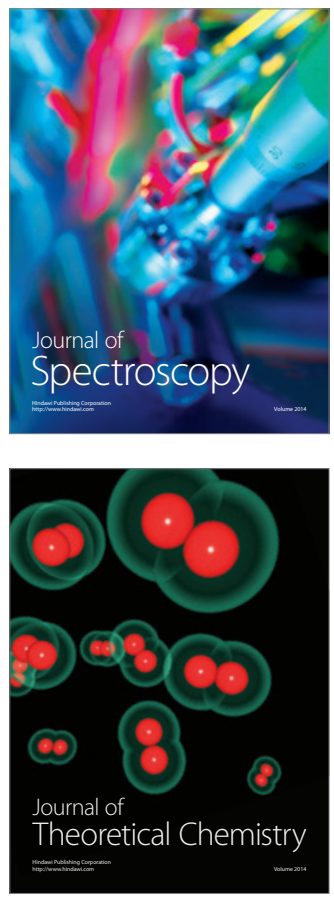
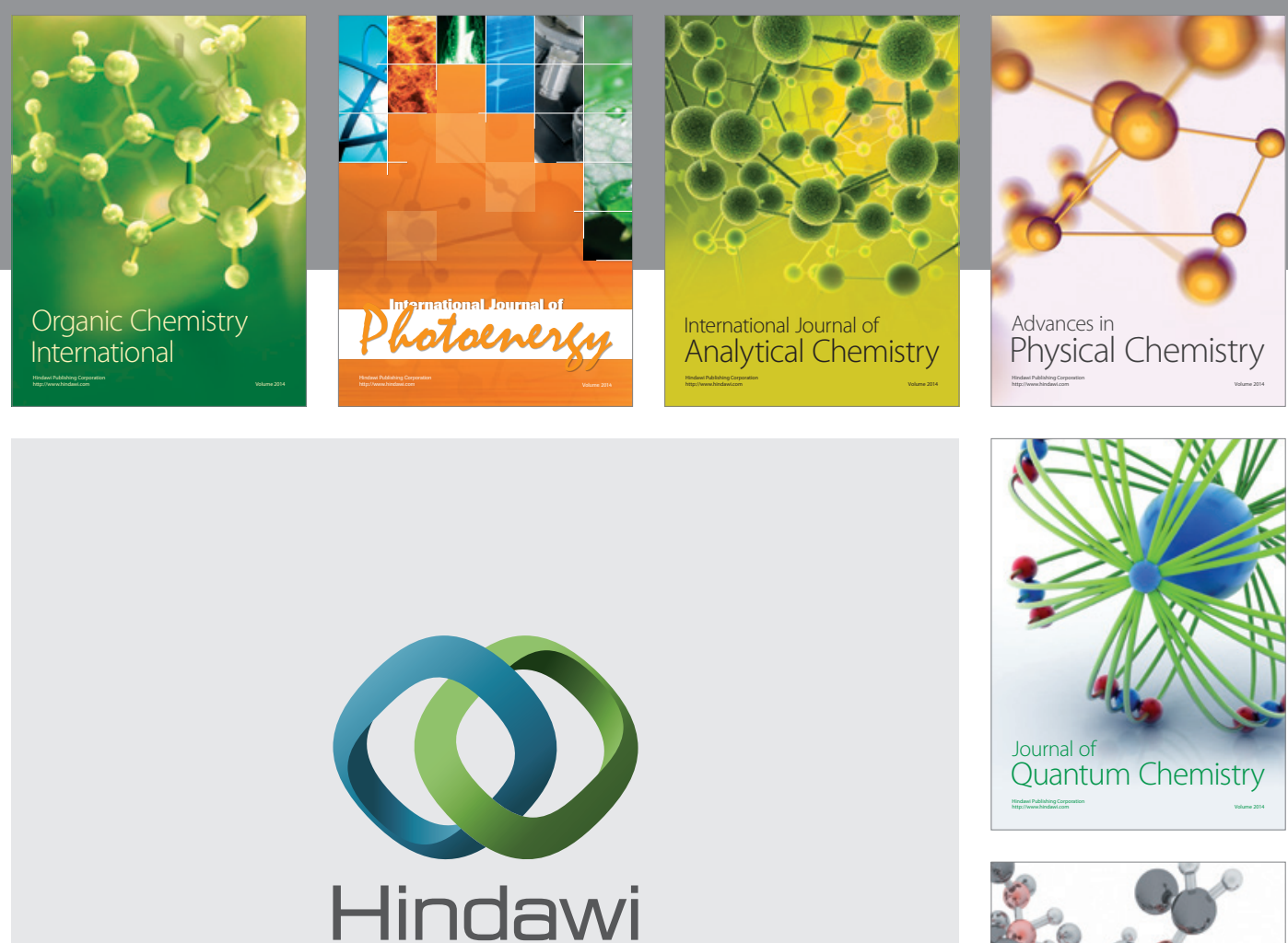

Submit your manuscripts at

http://www.hindawi.com

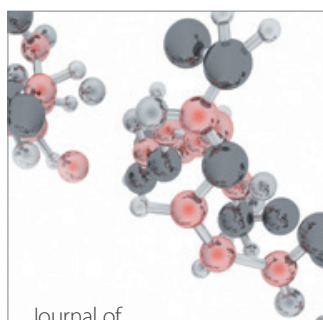

Analytical Methods

in Chemistry

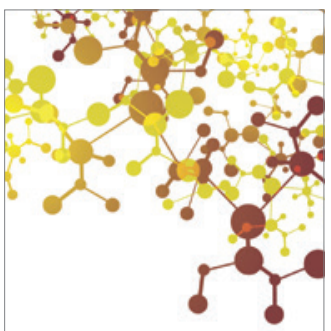

Journal of

Applied Chemistry

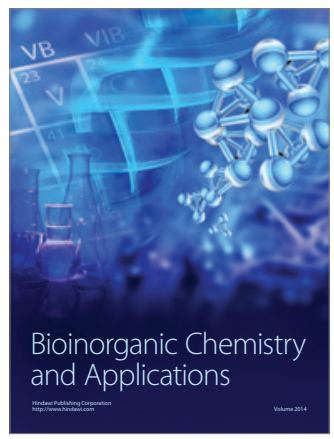

Inorganic Chemistry
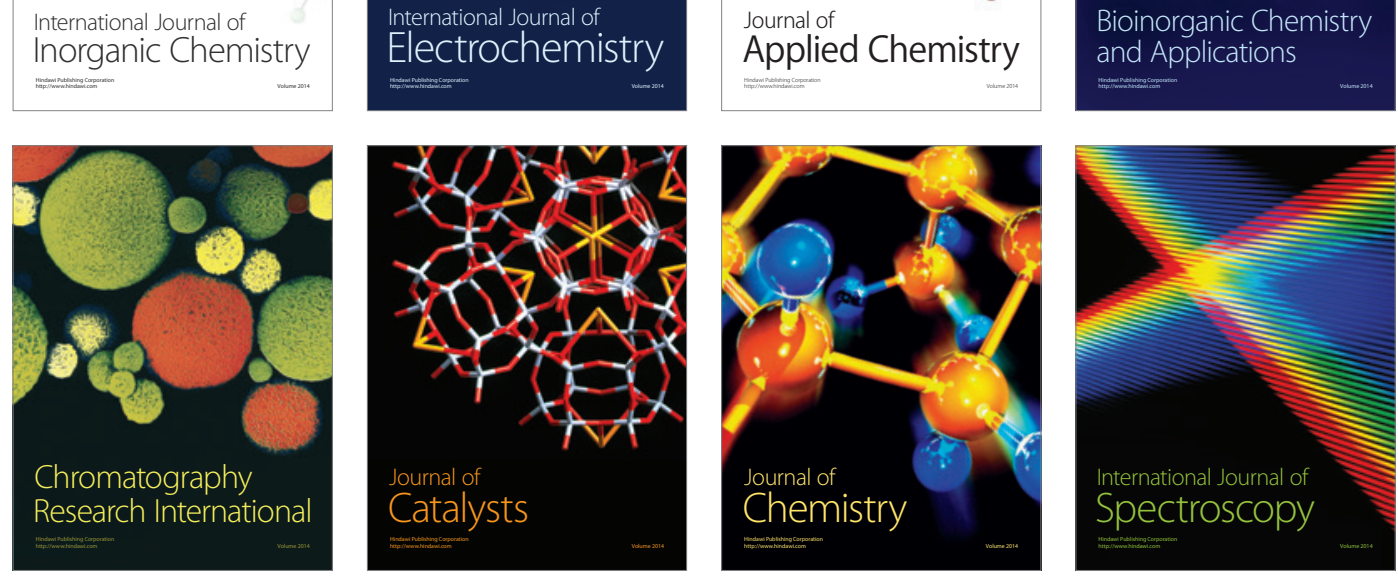